\title{
THE EFFECT OF TREE CANOPY STRUCTURE ON SPATIAL RAINFALL REDISTRIBUTION DURING POST-ERUPTION RECOVERY OF MOUNT MERAPI, JAVA ISLAND
}

\author{
Ahmad Reza Kasury ${ }^{1}$, *Rachmad Jayadi ${ }^{1}$ and Joko Sujono ${ }^{1}$ \\ ${ }^{1}$ Department of Civil and Environmental Engineering, Faculty of Engineering, Universitas Gadjah Mada \\ Yogyakarta, Indonesia
}

*Corresponding Author, Received: 02 Sept. 2021, Revised: 04 Oct. 2021, Accepted: 17 Oct. 2021

\begin{abstract}
The tree canopy around Merapi Volcano, Yogyakarta, Indonesia, has a unique structure. The frequency of volcanic eruptions influences the uniqueness of the structure, as it is a response to volcanic ash and rainfall characteristics. This research was conducted on eight species that have different canopy structures. In contrast to the trees canopy that was not affected by eruptions, the tree canopy around the Volcano has more dynamic canopy surface characteristics during the recovery period. The redistribution of rainfall in the tree canopy was traced by calculating unit area discharge and droplets' probability in each canopy structure segment. The results of empirical throughfall calculation and throughfall direct observation were tested using ANOVA. Most of the throughfall occurs simultaneously under the canopy during rain with a depth of $3.5-$ $72.5 \mathrm{~mm}$ or intensity of $10-20 \mathrm{~mm} /$ hour (observed $=58 \%$ and empirical $=57 \%$ ). The existing range of rainfall intensity or rainfall depth shows that the process of redistribution of rainfall in the canopy has time constraints and canopy storage capacity constrain. The canopy surface characteristics have a more significant effect than the canopy structure on the redistribution of rainfall. The canopy surface serves as a sheet of rainfall concentration to the next section. The important canopy surface structure parameters to rainfall concentration are leaves characteristics, branches stiffness, and crown density. Knowledge of the tree canopy's rainfall flow distribution process will help manage conservation-based rehabilitation activities in areas prone to volcanic disasters.
\end{abstract}

\section{Keywords: Rainfall redistribution, Canopy parameter, Empirical method, Throughfall distribution}

\section{INTRODUCTION}

Land cover recovery is strongly influenced by the type of disturbance, the period and area affected, abiotic conditions that suppress other abiotic factors and interactions between biotic components on a spatial scale [1]. Succession after a volcanic eruption is an activity that integrates vegetation factors and abiotic components, such as soil and rainfall. The interaction between biotil and abiotic components significantly influences the posteruption succession. Succession of volcanoes have shown that vegetation characteristics have a significant influence on land recovery [2].

Merapi Volcano is one of the most active volcanoes in Indonesia. Since 2000 Merapi Volcano has had an eruption frequency of 2 to 5 years. Between 2000 and 2019, Merapi Volcano experienced six significant eruptions [3]. During this period, Mount Merapi experienced six significant eruptions. The frequency and impact of the Merapi Volcano eruption substantially influence tree characteristics and the behavior of the people around the Volcano. Despite having a close eruption frequency, spatially and temporally, the trees around Merapi Volcano have a chance to recover. Land cover restoration has an impact on the micro-hydrology around Merapi Volcano Java.
The tree canopy structure plays a vital role in the rainfall redistribution into throughfall $(T f)$ and stem flow $(S f)$. The density of the canopy affects the dimensions of $T f$ droplets, kinetic energy, and reinterception by the canopy below [4].

This study observed the dominant trees that represent the tree architecture around Merapi Volcano. In addition, these tree species are commonly found in areas around the other active volcanoes of Java Island. Knowledge of the rain redistribution process by the canopy will provide insight into community tree management.

The canopy of woody trees was a dynamic multi-segment structure. Each canopy layer had a different response to the rainfall redistribution. The concentration of raindrops on the leaf surface was determined mainly by leaf roughness, surface free energy, and work-of-adhesion [5]. The canopy layer will hold the concentration of raindrops on the leaf surface, dripping by gravity or flowing to the next canopy segment.

\section{RESEARCH SIGNIFICANCE}

Global climate change has been observed through terrestrial change. The terrestrial component, considered one of the crucial components in climate modeling, is the tree canopy. 
The ability of tree canopies to hold and redistribute rainfall significantly affects the formation of surface runoff and flow concentration in the watershed [6].

Land used that was converted to agroforestry is potential for water management [6]. In secondary forest and growing forest (succession forest), variation of canopy partition is caused by dynamic natural process. The partition in these forests tends to get smaller, and the forest canopy is closer to a certain extent [7].

The study of rainfall redistribution by single trees is getting more detailed attention from researchers [8], which is in line with the need to understand partial and micro hydrological cycles. Previous studies have shown the effect of canopy structure on the rainfall redistribution process [4] but did not give detailed rainfall redistribution flow in the canopy structure. This study investigated the interaction between tree canopy structure parameters and rainfall characteristics. The results of this study provide an overview of tree canopy management.

\section{THEORY}

\subsection{Canopy Surface Flow}

The canopy surface of a tropical tree has a dynamic structure with a curved shape [9]. Water flows on the canopy surface are significantly influenced by the characteristics and structure of the canopy. The mass water transfer of each element in the same or different layer is influenced by the interactions between the leaf blades [10]. The water on the canopy surface flows along the canopy surface or is dropped within the canopy gaps. The water that flows through the canopy gap fills the canopy storage $(S)$ [9]. Water flow on the canopy surface flows once the canopy changes its form [11]. Equation (1) describes the flow continuity of the canopy surface.

$Q c s_{\text {down }}=\int_{0}^{\frac{\pi}{2}} \overline{A_{i}} \cdot T_{(\theta, z)} \cdot \operatorname{prob} q_{c s} d(\theta)$

where $Q c s_{\text {down }}=$ discharge at the canopy surface in $\mathrm{mm}^{3} / \mathrm{s} ; T_{(\theta, \mathrm{z})}=$ gap or porosity in the canopy [12]; $\overline{A_{i}}=$ average area of leaf blade in $\mathrm{mm}^{2} ; q_{c s}=$ width unit of canopy surface discharge in $\mathrm{mm} / \mathrm{s}$; and $\theta=$ vertical leaf angle in degree [13].

Canopy characteristics influence the distribution of raindrops above the leaf to twigs and branches [14]. In the early stages of flow distribution above the leaf, rainfall is assumed to be evenly distributed over the leaf [15]. Rainfall flow distribution on the canopy surface has been formed on the leaves with $90^{\circ}$ deformation. Leaf deformation occurs after the $C_{\min }$ exceeds the limit. In simple leaves, the leaves angle affects the gaps in the canopy [16], and $C_{\min }$ slowly exceeds the limit [17].

The canopy gap $\left(T O_{(\theta, z)}\right)$ is strongly influenced by leaf density and leaf angle [16]. Gap or canopy porosity describes the characteristics of the canopy cover of each tree segment. As soon as the minimum canopy surface holding capacity $\left(C_{\text {min }}\right)$ has exceeded the limit, water flowed immediately. In this condition, the water depth above the leaf surface is assumed to be the same as the critical depth $\left(y_{c}\right)$. The $y_{c}$ can be written as Eq. (2) as follows [18]:

$y_{c}=\sqrt[3]{\frac{q_{c s}^{2}}{g}}$

where $y_{c}=$ critical depth or water depth above the leaf surface just before it flows through the surface, in $\mathrm{mm}$; and $g=$ acceleration due to gravity $\left(\mathrm{mm} / \mathrm{s}^{2}\right)$;

Canopy surface critical depth occurs during the initial phase of filling the canopy storage. Once the critical depth at the surface of the canopy has exceeded the limit, water flows to the next segment $\left(q_{c s}\right)$. The value of $q_{c s}$ is based on the kinematic viscosity of the leaves just before the water flows, as shown in Eq. (3), and the flow velocity is presented in Eq. (4) [18]. The flow distribution is formed under the canopy, influenced by gravity and interactions between canopy segments [4]. The discharge below the canopy surface $\left(\operatorname{Qcs}_{\text {down }}\right)$ is estimated with [18]:

$$
\begin{aligned}
& q_{c s}=\frac{g}{3 v_{k}}\left(y_{i}\right)^{3} \cos \theta=\frac{g}{3 v_{k}}\left(I-C_{\min }\right)^{3} \cos \theta \\
& \bar{v}_{c s}=\frac{g}{3 v_{k}}\left(I-C_{\min }\right)^{2} \cos \theta \\
& y_{c s}=\frac{q_{c s}}{v_{c s}} \cdot \lambda_{0(\theta, Z)} \cdot a_{l(Z)} \cdot \Delta y_{l} \\
& Q c s_{d o w n}=f_{l} \cdot q_{c s} \cdot v_{c s} \cdot T_{(\theta, z)} \cdot C P A
\end{aligned}
$$

where $v_{k}=$ kinematic viscosity of water in $\mathrm{mm}^{2} / \mathrm{s} ; y_{i}$ $=$ depth of water above the leaf surface at time $i$ in $\mathrm{mm} ; I=$ rainfall intensity in $\mathrm{mm} / \mathrm{min} ; \bar{v}_{c s}=$ average velocity of water over the canopy surface in $\mathrm{mm} / \mathrm{min} ; f_{l}=$ coefficient of leaf configuration on twigs for $0<f_{l}<1 ; \lambda_{0(\theta, Z)}=$ ratio of leaf shade to previous leaf segment; $a_{l(Z)}=$ leaf density per area observed; $T_{(\theta, Z)}=$ canopy gap; $\Delta y_{l}=$ distance between leaves in average $(\mathrm{mm})$ and $C P A=$ Crown Projection Area.

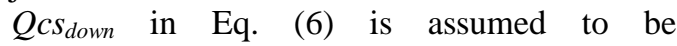
simultaneously below the canopy surface. The distribution of $Q \operatorname{cs}_{\text {down }}$ was different for each tree, even in the same species. The difference in $Q c s_{\text {down }}$ 
occurs due to different dimensions of the branches and twigs, distribution, and angles of the branches and twigs, phyllotaxis, and angular leaf distribution to the branches. Plant Area Index (PAI) has a more significant effect on Leaf Area Index (LAI) [7]. LAI can be described as density and leaf density based on light interpretation [19].

\subsection{Flow-Through to Canopy Storage}

Water flows to the canopy surface through the funnel to fill the canopy storage $(S)$ [20]. In the woody tropical pine trees, filling the canopy storage starts by $Q c_{\text {down }}$ flows from twigs to branches [21]. The change in canopy storage volume $\left(V_{s}\right)$ according to the time can be written as follows:

$\frac{d V_{S}}{d t}=\left(f_{t} \cdot Q c_{d o w n}\right)-V s_{t}-V s_{s}-V e_{c s}$

where $V_{s}=$ canopy storage volume in $\mathrm{mm}^{3} ; f_{t}=$ branch flow coefficient for $0<f_{t}<1 ; V e_{c s}=$ water evaporation volume on the crown surface in $\mathrm{mm}^{3}$; $V s_{t}=$ the volume of water content on the surface of the twigs in $\mathrm{mm}^{3}$; and $V s_{s}=$ the volume of water content on the branches surface in $\mathrm{mm}^{3}$.

In the interception tank model [22], $T f$ occurs after the minimum canopy storage exceeds the limit, even though it is not saturated $\left(S_{\min }<\mathrm{S}<S_{\max }\right)$ [17]. In this phase, $T f$ has not occurred in all CPAs [23]. $T f$ occurs under the entire canopy after the saturated canopy [20]. The water flow occurs in 2 phases, i.e., dripped and flowed [4]. The flow that occurs in the branches only happens after $V s_{t}$ and $V s_{s}$ in Eq. (7) are saturated.

Water flows through a twig after the water flow has a more significant force than the friction force $\left(F_{t \text {-rigid }}\right)$. If the twig capacity to recharge water flows to branches is assumed as $C_{\min }$ [11], then the friction force in the twig surface of the unit width $\left(F_{t-r i g i d}\right)$ is calculated using Eq. (8).

$$
F_{t-\text { rigid }}=\gamma \cdot \bar{\phi}_{t} \cdot y_{t}=\overline{A_{t}} \cdot C_{\min } \cdot \rho_{w} \cdot g
$$

The water that flows to the twig on width unit $\left(m_{t}\right)$ towards the branch for a particular duration of time can be written as follows:

$m_{t}=q_{c s} \cdot \bar{\phi}_{t} \cdot \cos \beta \cdot \rho_{w} \cdot \Delta t$

The force that occurs on the twig due to the canopy surface flow to the branch for a particular time duration $\left(F_{t i}\right)$ is calculated with Eq. (10). On the twig, the force has changed due to velocity changes [5]. The velocity in the wide twig is

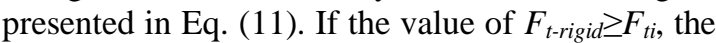
water will be detained in the twig and became part of $S_{\min }[17]$.

$$
\begin{aligned}
& F_{t i}=m_{t} \cdot a_{t}=\left(q_{c s} \cdot \overline{A_{t}} \cdot \sin \beta \cdot \rho_{w} \cdot \Delta t\right) \cdot\left(\frac{\overline{v_{c s}}}{\Delta t}\right) \\
& \overline{v_{t}}=\overline{v_{c s}} \sin \beta
\end{aligned}
$$

The force that rapidly changes in the channel downstream can be described as the relationship between the large unit of discharge and the difference in water depth at upstream and downstream [18]. For water that flows through the twigs, the water depth at the upstream is assumed as the $S_{\min }$, and the downstream depth is $y_{c s}$ [4]. The water depth in the twigs $\left(y_{t}\right)$ is written in Eq. (12) [5]. Thus, the flow at the meeting point between twig and branch for each unit area $\left(q_{t s}\right)$ in a particular time is calculated with Eq. (13).

$$
\begin{aligned}
& y_{t}=\left(y_{c s}-S_{\min }\right) \cos \beta+S_{\text {min }} \\
& q_{t s}=\varphi_{t s} \cdot \overline{y_{t}} \cdot \overline{v_{t}}
\end{aligned}
$$

The flow force on the branch's surface is assumed to be evenly distributed [10]. The increase in angle $\beta$ also increases the probability of water dripping off the branch [24]. The flow force on the branch happens at the point closest to the branch after the branch was saturated with water as shown in Eq. (14).

$$
F_{t i+1}=F_{t i}+\left(\varphi_{t s}\left(q_{t s} \cdot \overline{A_{t}} \cdot \sin \beta \cdot \rho_{w}\right) \cdot \overline{v_{t}}\right)
$$

where $F_{t i}=$ flows force that occurs on the surface of the branch in $\mathrm{mm}^{3} ; m_{t}=$ water mass on the twig in gr; $\varphi_{t s}=$ ratio of the distance between the closest leaves on the twig to the twig length for $0<\varphi_{t s}<1$; $\overline{A_{t}}=$ area of twig surface per segment in $\mathrm{mm}^{2} ; y_{t}=$ flow depth on the branch surface in $\mathrm{mm} ; \overline{v_{t}}=$ average flow velocity above the twig in $\mathrm{mm} / \mathrm{s}$.

\subsection{Throughfall Distribution Below Canopy}

Rainfall redistribution to a throughfall starts after the saturated canopy surface [25]. The flow from the twigs to the branches $\left(q_{t s}\right)$ is partly dripped as a $T f_{t-d r i p}$ [17]. The depth of $T f_{t-d r i p}$ at $C P A$ can be estimated by Eq. (15).

$T f_{t-d r i p}=\frac{\varphi_{t s} \cdot F_{t i} \cdot q_{t s} \cdot \Delta t \cdot \cos \beta \cdot \overline{L_{t}} \cdot C P A}{n_{t} \cdot}$

The canopy structure gives influence to the $q_{t s}$. The $q_{t s}$ flows in the branch once the flow force is greater than the flow resistance force in the branch $\left(F_{s}>F_{s-r i g i d}\right)$ [18]. If $F_{s} \leq F_{\text {s-rigid }}$, there is no water flow along the branch, and water fills the branch segment near the branch point. The water depth in the 
downstream area is influenced by upstream discharge and the channel friction coefficient [5]. The water depth at the saturated branch can be assumed as the ratio between dry weight $\left(s_{d r y}\right)$ and wet weight of the branch $\left(s_{w e t}\right)$ [23]. Thus, the $F_{\text {s-rigid }}$ of the width can be calculated by Eq. (16).

$$
F_{s-r i g i d}=\overline{A_{s}} \cdot \frac{s_{d r y}}{s_{w e t}} \cdot \rho_{w} \cdot g
$$

The flow of water from branches to stem starts at an angle formed between the stem and the branch, i.e., between $0^{\circ}-90^{\circ}(0-\pi / 2)$. Once the flow occurred on the branch's junction, the water depth on the branch's surface $\left(y_{s}\right)$ is estimated by Eq. (17).

$$
y_{s}=\left(\frac{q_{t s} \cdot F_{s-\text { rigid }}}{\sqrt{\sin \alpha}}\right)^{3 / 5}
$$

Branches storage $\left(v_{s}\right)$ is the branch surface that effectively holds water [26]. Water has not been evenly retained over the branch surface [27]. On the canopy with an angular distribution between $2^{\circ}$ $60^{\circ}$ from the horizontal axis, the distribution on the branch flows to the underside of the branch [24]. The branches storage volume calculation can be written as Eq. (18).

$v_{s}=v_{t} \cos \alpha$

The discharge per unit area on the branch is as follows.

$$
q_{s}=y_{s} \cdot \overline{v_{s}}
$$

The diameter and roughness of the branches have a significant effect on the depth of direct water droplets $\left(T f_{\text {drip }}\right)$ [14], or the flow on the branches, or drop from the limb $\left(\right.$ can $\left._{\text {stem-drip }}\right)$ [17]. There is no splash of throughfall in rainfall with intensity $(I)$ less than $100 \mathrm{~mm} /$ hour [28].

The flow that occurs at the joint area of the twigs and branch $\left(q_{t s}\right)$ is assumed to flow through the branch due to gravity [20]. Water flows and fills up the branches and canopy capacity $\left(V_{s}\right)$. The process of water drip or flow on the branches is different from the processes that occur on the surface of the canopy and branches. To calculate $V_{s}$ is presented in Eq. (20).

$$
V_{s}=\frac{q_{s} \cdot \overline{A_{s}}}{F_{s-\text { rigid }}}
$$

Water flows from twig to branches starts to drip at the twig growth point. The depth of $T f_{\text {s-drip }}$ is influenced by the volume of water flow to the branch and the number of twig points on the branch [7]. Assuming that the growing point of the branch is saturated, $T f_{s-d r i p}$ depth can be written in Eq. (21).

$$
T f_{s-d r i p}=\frac{q_{s} \cdot \Delta t \cdot \cos \alpha \cdot C P A}{n_{s} \cdot V_{s}}
$$

Water from the twig to the branch is not completely dripped as $T f_{\text {s-drip. }}$. Some of the water flows along the branches due to gravity. Water flows to filled branches storage or became a stemflow or drips onto the ground. Water drips from the branch to the ground $\left(\right.$ can $\left._{\text {stem-drip }}\right)$ can be calculated by Eq. (22).

$\operatorname{can}_{\text {stem-drip }}=\left(\frac{q_{s} \cdot . \Delta t \cdot L_{s} \cdot V_{s}}{n_{t} \cdot \sqrt{\cos \alpha}}\right)^{3 / 5}$

$T f^{\prime} s$ depth is the throughfall cumulative value from twigs and branches, as shown in Eq. (23).

$T f=T f_{t-d r i p}+T f_{s-d r i p}+c a n_{\text {stem-drip }}$

where $T f_{\text {s-drip }}=$ depth of $T f$ from the branch at $C P A$ in $\mathrm{mm}$; can $_{\text {stem-drip }}=$ drip from the lowest crown layer to the soil surface in $\mathrm{mm} ; T f_{t-d r i p}=$ depth of $T f$ from branches at $C P A$ in $\mathrm{mm} ; \alpha=$ angle of the branch to the horizontal axis in degrees; $V_{s}=$ volume of the branch storage width in $\mathrm{mm}^{3} ; \varphi_{\mathrm{ts}}=$ flow coefficient due to twig flexibility with $0<\varphi_{\text {ts }}$ $\leq 10) ; n_{\mathrm{t}}=$ number of branch points; $n_{\mathrm{s}}=$ number of canopy column branches; $A \mathrm{~s}=$ surface area of the branch in $\mathrm{mm}^{2} ; y_{c-s}=$ depth of water in the branch before it flows on the branch surface in $\mathrm{mm} ; \varphi_{\mathrm{vs}}=$ stem funneling ratio for $0<\varphi_{\mathrm{vs}}<1 ; V_{s}=$ depth of water retained in the branch for a specified time in $\mathrm{mm} ; \overline{L_{s}}=$ average length of the branch in $\mathrm{mm} ; \bar{L}_{t}=$ average length of twigs in $\mathrm{mm} ; q_{\mathrm{s}}=$ flow rate in the branch width in $\mathrm{mm} ; s_{d r y}=$ weight of the branch in dry conditions in gr; $s_{\text {wet }}=$ weight of the branch in wet conditions in gr; $\Sigma n t=$ the number of branches that grows along the tree branch.

\section{METHODOLOGY}

Meteorological factors and $\begin{gathered}\text { canopy } \\ \text { rainfall }\end{gathered}$
characteristics significantly affect
redistribution by the trees [29]. Canopy
characteristics that affect the process of rainfall
redistribution, i.e., crown density [20], canopy
structure [24], composition or cropping patterns,
and tree adaptation to the seasons [11]. Klamerus-
Iwan [27] stated that it is more challenging to have
a standard of canopy factor in Tf redistribution on
all trees, both the same or different species. The
thickness of the canopy [4], the slope of the


branches and twigs, the composition of the crown [20], the morphology of the trunk, the angle of the leaves, the turgidity of the leaves [9], the size and shape of the leaves, and the nature of the hydrophobicity of the leaves are biotic parameters that affect $T f$ [28].

\subsection{Research Location}

The research was conducted in the Petung village, Kalurahan (sub-district) Cangkringan, located on the south side of Merapi Volcano. The location was categorized as a severe and moderate level of damage due to the eruption of Merapi in 2010. This location is chosen because it is relatively protected from extreme climatological changes [30]. The research location is relatively protected from strong winds. Calder [31] states that wind gusts significantly affect the throughfall (Tf) droplet characteristics. Wind gusts affect the interaction between canopy segments [11]. The interaction between canopy segments affected water flows into the canopy storage or between canopy segments. Petung village was chosen to minimize the probability of bias data due to extreme rainfall. Research location point relative to the level of vegetation damage is shown in Fig. 1 modified from the corresponding map [32].

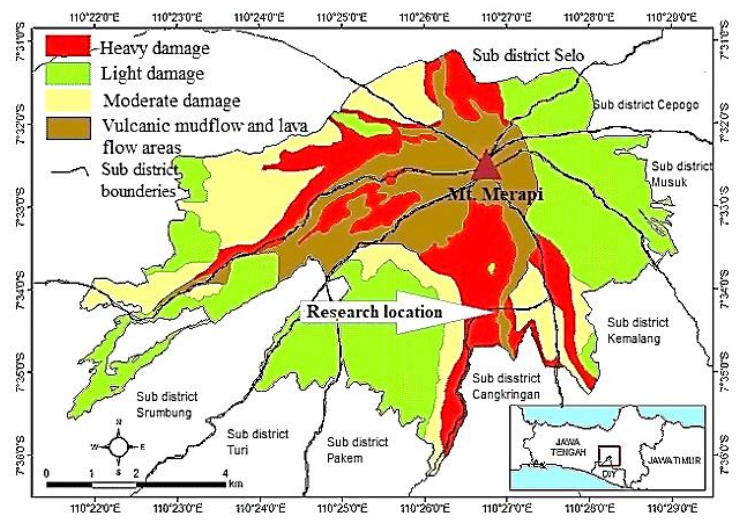

Fig.1 Research location

The level of vegetation damage in Fig. 1 identified based trees condition at 2010 eruption. In heavy damage, all tree canopies was wither and fall off (leaves and branches). At moderate damage, only compound leaves trees was wither and fall off. Broadleaves tree tend to wither but not fall. In light damage, the entire tree canopy only withers.

Petung village is one of the settlements directly affected by the Volcano eruption [32]. Before the 2010 Merapi eruption, Petung village was one of the producers of Coffea canephora and cow's milk in Yogyakarta [33]. After the 2010 eruption, all Petung residents were relocated from the eruption danger zone. Most of the population still used the land in the previous area for horticultural plantations and animal husbandry [31, 32]. In addition, this area has developed into a tourist location for disaster education.

Measurement of field data in the Petung village settlement was carried out from December 2016 to February 2019. Currently, the spot, which is the research area, has turned into a secondary forest and traditional farm with 12 species of woody trees and four shrubs. The research area characterized by sandy soil with hilly and relatively flat topography [34].

\subsection{Trees Selection}

The tree canopy is a dynamic structure with very heterogeneous characteristics. Heterogeneity in the tree canopy occurs in the same species or between species. In this study, the selected species represent the characteristics of vegetation canopy around volcanoes on Java Island [32]. The tree canopy characteristics that were used as the sample are presented in Table 1.

Table 1. Characteristics of the tree canopy samples

\begin{tabular}{|c|c|c|c|}
\hline $\begin{array}{l}\text { Species } \\
\text { code }\end{array}$ & Species name & Phyllotaxis & $\begin{array}{c}\text { Branch } \\
\text { orientation }\end{array}$ \\
\hline 1 & $\begin{array}{c}\text { Acaciad wild. } \\
\text { Australi }\end{array}$ & Sparsa & Patens \\
\hline 2 & Artocarpus hete. & Sparsa & Patens \\
\hline 3 & Pinus merk. & Verticillata & Patens \\
\hline 4 & Ceiba pent. Randu & Sparsa & Horizontalis \\
\hline 5 & Alstonia sch. & Verticillata & Horizontalis \\
\hline 6 & $\begin{array}{c}\text { Coffea can. } \\
\text { Robusta }\end{array}$ & Opposita & Declinatus \\
\hline 7 & Leucaena leu. & Sparsa & Patens \\
\hline 8 & Tectona gran. & Sparsa & Patens \\
\hline
\end{tabular}

In general, the tree canopy around Merapi Volcano has four forms of canopy with three leaf shapes. On the slopes of Merapi, the type of canopy is parabolic, elliptic, cone, and spheroid. Meanwhile, the composition of leaves is dominated by compound leaves, needle leaves, and simple leaves. Most of the woody trees' branch's characteristics are patens and horizontalize. The observation on crown characteristics in this study includes the diameter $(\phi)$, leaf angle $(\theta)$, twigs angle $(\beta)$, and the angle between the branch and tree $(\alpha)$. The characteristics of the trees that became the observation parameters are described in Fig. 2 and Table 2.

Deformation of the tree canopy is caused by wind gusts, snows, and rainfall energy [35]. In the sparse tree, canopy characteristics have a very significant effect on rainfall redistribution [15]. Holder [24] states that rainfall-water flow from the surface to the canopy is influenced by leaf angle and leaf hydrophobicity. 


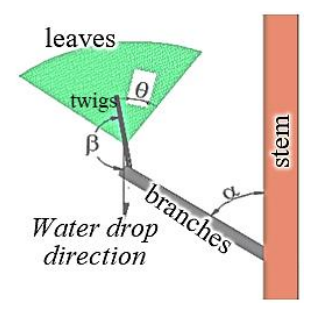

Fig.2 Measured parameters sketch

Table 2 Diameter and angular distribution of twigs and branches

\begin{tabular}{|c|c|c|c|c|c|}
\hline \multirow{2}{*}{$\begin{array}{c}\text { Species } \\
\text { Code }\end{array}$} & \multicolumn{2}{|c|}{$\phi(\mathrm{mm})$} & \multirow{2}{*}{$\alpha^{\circ}$} & \multirow{2}{*}{$\beta^{\circ}$} & \multirow{2}{*}{$\theta^{\circ}$} \\
\hline & Twig & Branch & & & \\
\hline 1 & 3.7 & 14.0 & 74.5 & 30.0 & 35.0 \\
\hline 2 & 5.0 & 43.5 & 38.0 & 72.0 & 37.0 \\
\hline 3 & 5.2 & 22.0 & 41.5 & 36.5 & 57.0 \\
\hline 4 & 3.9 & 48.5 & 43.5 & 56.0 & 74.0 \\
\hline 5 & 5.0 & 32.5 & 45.5 & 38.0 & 32.5 \\
\hline 6 & 3.4 & 13.5 & 55.5 & 87.0 & 74.0 \\
\hline 7 & 3.6 & 13.5 & 73.0 & 25.0 & 69.0 \\
\hline 8 & 3.8 & 49.0 & 57.5 & 43.0 & 47.5 \\
\hline
\end{tabular}

The canopy density was estimated using $L A I$ and was measured by the hemispherical method (Table 3). The photo was taken using a DX NIKKOR $10.5 \mathrm{~mm}$ f / $2.8 \mathrm{G}$ AF lens with the Gap Light Analyzer ver2.0 [19].

Table $3 L A I$, twigs, and branches lengths

\begin{tabular}{cccc}
\hline \multirow{2}{*}{$\begin{array}{c}\text { Species } \\
\text { Code }\end{array}$} & $L A I$ & \multicolumn{2}{c}{$\mathrm{L}(\mathrm{mm})$} \\
\cline { 3 - 4 } & & Twig & Branch \\
\hline 1 & 2.5 & 105 & 328 \\
2 & 3.8 & 54 & 1425 \\
3 & 2.5 & 130 & 1661 \\
4 & 2.3 & 172 & 1480 \\
5 & 3.0 & 75 & 633 \\
6 & 3.2 & 63 & 1074 \\
7 & 2.3 & 75 & 363 \\
8 & 3.0 & 74 & 1765 \\
\hline
\end{tabular}

\subsection{Canopy Surface Storage Capacity}

The estimation of canopy surface capacity $(C)$ was calculated using saturated leaf weight [36]. In this study, leaf weight was measured in two conditions. The water-saturated leaf weight was measured immediately after the water had dripped through the leaf tips and was assumed to be the maximum canopy surface storage $\left(C_{\max }\right)$. After 30 minutes, the leaf weight was considered as minimum canopy surface capacity $\left(C_{\min }\right)$.

Leaf weight measurement was carried out between 09:00 to 10:00 am. This period was chosen to reduce the effect of dew on the leaves' weight before spraying. The measurements were taken below the canopy of the sample trees and protected from direct sunlight. The wind speed ranged from 2-5 knots at the measurement time, and the air temperature was around $21-26^{\circ} \mathrm{C}$.

Analytic digital scales were used to measure leaf weights. There were 40 leaves taken from each tree to be observed. $C$ is considered to be evenly distributed above the leaves. The depth of $C$ was calculated with Eq. (24).

$$
C=\frac{W_{b}-W_{k}}{A_{d}}
$$

where $C=$ canopy surface storage capacity in $\mathrm{mm}$; $W_{b}=$ leaf weight after spraying until saturated or dripping in gr; and $W_{k}=$ leaf weight before spraying water in gr.

The canopy capacity can be assumed as the water depth that is evenly distributed over the surface. The measured value of $C_{\min }$, which is the highest value for each tree, is assumed to be the tree's critical depth $\left(y_{c}\right)$. Meanwhile, the highest measured value of $C_{\max }$ is considered as the minimum canopy storage capacity $\left(S_{\min }\right)$.

\subsection{Throughfall Distributed Collector}

The rainfall data in this study are collected by the volume and duration of rainfall and $T f$. All data obtained has been converted into rainfall intensity data in $\mathrm{mm} /$ hour.

The throughfall at each point was measured using a 3.2 liters PVC tube and inlet funnel with a diameter of $26.4 \mathrm{~cm}$. The funnel was placed horizontally (angle $0^{\circ}$ horizontal).

$T f$ collector was distributed under the canopy for each observed tree. The CPA was divided into four segments (A B C D). Each segment has a distance of $0.25 C P A$ radius on average. Fig. 3 has presented the $T f$ observation points under the tree canopy.

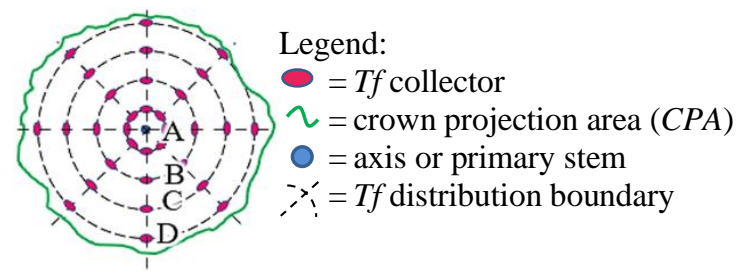

Fig.3 Tf collector placement below the canopy

The top surface of the inlet funnel was $40 \mathrm{~cm}$ above ground level. During data collection, the inlet of the $T f$ collector funnel the surrounding was cleared from grass obstructions. The description and placement of the $T f$ collector was shown in Fig.4. 


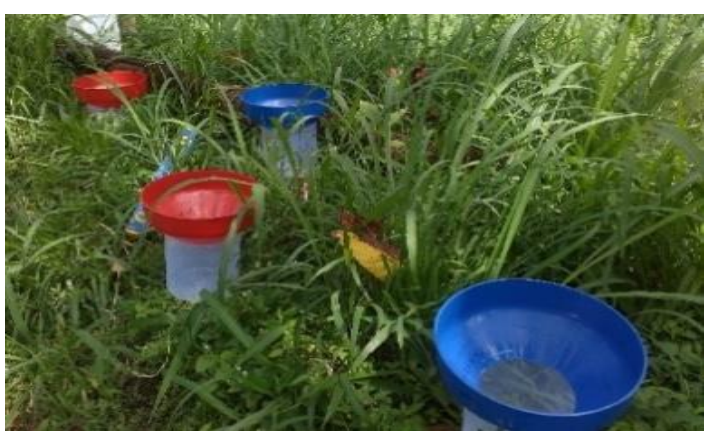

Fig.4 Description and placement of $T f$ collector

\subsection{Rainfall and Throughfall}

Rainfall data used is rainfall that occurs after the surface of the tree canopy is dry or occurs more than 10 hours since the end of the previous event. During the observation, 223 rainfall events were obtained. Rainfall data that entered the analysis criteria were 83 rainfall events.

The classification of rainfall intensity used is light rainfall intensity $(1-5 \mathrm{~mm} /$ hour or $0.5 \mathrm{~mm} /$ day - $20 \mathrm{~mm} /$ day), moderate rainfall intensity (5-10 $\mathrm{mm} /$ hour $20 \mathrm{~mm} /$ day $-50 \mathrm{~mm} /$ day $)$, heavy rainfall intensity $(10-20 \mathrm{~mm} /$ hour or $50 \mathrm{~mm} /$ day -100 $\mathrm{mm} /$ day), very heavy rainfall intensity ((> $20 \mathrm{~mm} /$ hour or $100 \mathrm{~mm} /$ day $-150 \mathrm{~mm} /$ day) and extreme rainfall intensity ( $>40 \mathrm{~mm} /$ hour or more than $150 \mathrm{~mm} /$ day) [37].

Although the observations were carried out at the same time, the response of the vegetation had a significant effect on the observation. Tf occurred after 20 minutes with a depth of $0.98 \mathrm{~mm}$. Fig. 5 shows the relationship between rainfall depth and duration that caused $T f$ in this study.

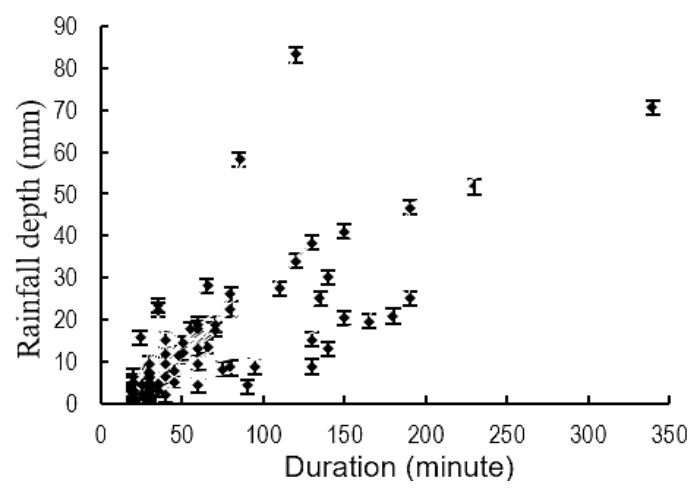

Fig.5 Rainfall depth and duration during $T f_{\text {observed }}$

This study shows that $T f$ occurs after rainfall depth $>10 \mathrm{~mm}$ with a duration of 30 minutes (rainfall with an intensity of $5 \mathrm{~mm} /$ hour). Most of Tf occurs at rainfall depths between $20 \mathrm{~mm}$ to 68 $\mathrm{mm}$ with a duration of 39 minutes to 71 minutes $(71 \%)$ or at rainfall intensity $(I)$ between 16.9 $\mathrm{mm} /$ hour to $57.5 \mathrm{~mm} /$ hour. In rainfall with a depth of $10 \mathrm{~mm}$ to $42 \mathrm{~mm}$ with a duration of less than 38 minutes $(15.8 \mathrm{~mm} /$ hour $<I<16.9 \mathrm{~mm} /$ hour $)$, the incidence of $T f$ was $29 \%$. The smallest ratio (4\%) was obtained in rainfall with a depth of more than $50 \mathrm{~mm}$ with a duration of more than 200 minutes (5 $\mathrm{mm} /$ hour $<I<15.8 \mathrm{~mm} /$ hour).

Fig. 6 shows, $89 \%$ Tf has occurred evenly in all vegetation. Significant differences began to occur due to the increasing duration of rainfall. For rainfall with a duration of more than 100 minutes, the surface characteristics of the tree canopy play a very important role. The increase in $T f$ depth in broadleaf trees was not as large as in compound leaf trees. The distribution of observations on each vegetation is presented in Fig. 6 .

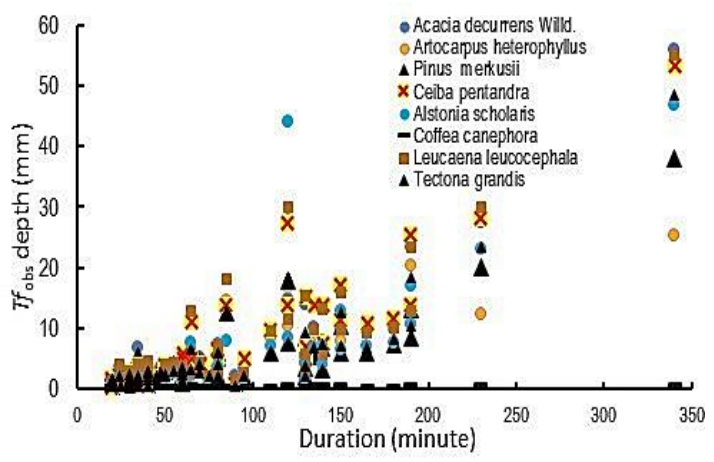

Fig.6 Tf $f_{\text {observed }}$ and rainfall depth $(P)$

\subsection{Throughfall Distribution Statistical Test}

ANOVA test is carried out on the depth of rainfall and tree species against $T f_{t-d r i p}, T f_{s-d r i p}$, can $_{\text {stem-drip }}$, and $T f_{\text {empirical }}$. This study obtained two events of light rainfall intensity, 17 events of moderate-intensity rainfall, 50 heavy rainfall, and 14 very heavy, respectively. The total data of rainfall events that caused a throughfall in the $C P A$ is 83 rain events.

All data are grouped by rainfall intensity. Each group is a subject of a 2-way significant test using ANOVA. A significance test is carried out on the rainfall depth $(P)$ and tree species. The significance levels are $1 \%$ and $5 \%$.

\section{RESULT AND DISCUSSION}

\subsection{Surface Canopy Distribution Aspect}

The leaves provide an overview of the canopy surface conditions in woody tropical trees. The azimuth and zenith distribution on the canopy leaves is random and symmetric throughout the canopy [10]. Leaves distribution in the tree canopy shows a two-parameter beta distribution. Leaves density, spacing, and vertical distribution have influenced the contact frequency between the 
canopy surface and raindrops [36]. It can be concluded that leaf characteristics play a significant role in grain distribution and $T f$ volume. $q_{c s}$ depth becomes a parameter to trace rainfall redistribution in the tree canopy.

Visual observation on these eight different tree species shows that the canopy surface of broadleaves trees has a more significant effect on rainfall redistribution than on needle trees [17,37]. Broadleaves trees, such as Artocarpus hete. and Tectona gran. have the largest sheet concentration area than Pinus merkusii. In addition, leaf distribution and leaves angle against the branches affect water distribution on the tree's canopy surface. Eq. (3) shows that the depth of $q_{c s}$ in the Artocarpus hete. is more extensive than Tectona gran The results of the calculation of $\mathrm{q}_{\mathrm{cs}}$ for each species have been presented in Fig.7.

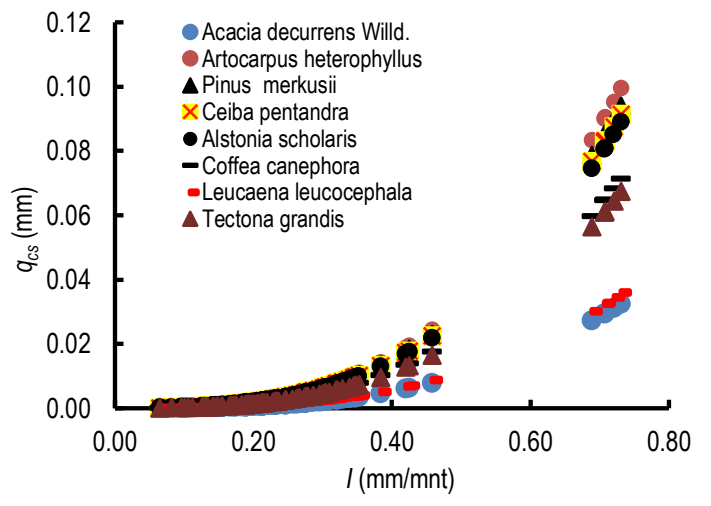

Fig.7 $q_{c s}(\mathrm{~mm} / \mathrm{sec})$ vs $I(\mathrm{~mm} / \mathrm{sec})$

Apart from the canopy surface structure, the increasing depth of $q_{c s}$ is also influenced by the rainfall intensity. The calculation result shows that the increase of $q_{c s}$ value against $I$ has a polynomial distribution trend.

This study shows that $q_{c s}$ in the Acacia $d$ wild. is similar to $q_{c s}$ in Leucaena leu. Canopy surface characteristic and leaf distribution on the Acacia d wild. and Leucaena leu. is almost similar. The increase in $q_{c s}$ for each species is various at $I>0.35$ $\mathrm{mm} / \mathrm{min}$. The difference in the cumulative increase of $q_{c s}$ is more significant after $I>0.45 \mathrm{~mm} /$ minute.

This study shows that the leaf angle distribution and the interaction between segments on the canopy surface give a more significant effect than the shape and leaf area ratio. Flow distribution to the branches formed on Pinus merkusii is considered to be better than that in the Acacia $d$ wild. and Leucaena leu. The surface of Acacia $d$ wild. and Leucaena leu. is more responsive to rainfall than the canopy surface of other species. This study found that the interactions at the canopy have a more significant effect on the canopy capacity than the leaf area factors.
The canopy surface capacity affects the throughfall process. The calculation results show that flow distribution on the canopy surface is strongly influenced by the response of the leaves on the branches to the rainfall. In this study, the canopy surface flow through to the branches is not always become $q_{t}$.

During water flow-through processed, the branch characteristics and distance between leaf and the branch base significantly affect. The result of branch flow calculation with Eq. (13) is presented in Fig.8.

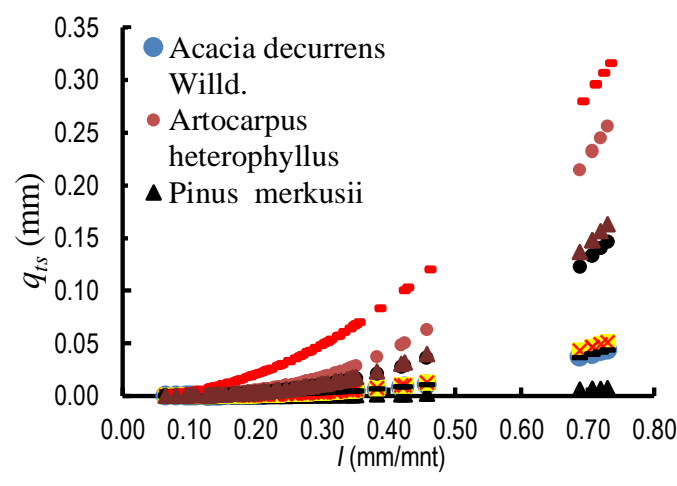

Fig.8 $q_{t s}(\mathrm{~mm} / \mathrm{sec})$ vs $I(\mathrm{~mm} / \mathrm{sec})$

The flow on the branches' surface is formed because of the interaction between canopy segments and the flow in the canopy surface. The water flow process on the branches has a similar character to the flow on the canopy surface.

Water flow duration and depth that occurs when the canopy surface has been saturated, is determined by the canopy structure [8]. The dynamic structure of the canopy causes a complex flow redistribution process. This research shows that the flow from the canopy surface and raindrops from the leaves gap have been fragmented.

\subsection{Troughfall Distribution}

The flow on the canopy surface is separated into two zones, the leaf canopy surface zone and the branches canopy surface zone. Visual observation shows that the throughfall started at the twigs canopy zone. $q_{c s}$ and canopy droplets are segmented and distributed on the twigs.

The direction of $q_{t s}$ is determined by the characteristics of the species. The species with horizontal/paten canopy structure (such as the Acacia $d$ wild. and Leucaena leu.), tends to have water flows to the tips of the leaves. Meanwhile, in trees with upward inclined twig structures (Artocarpus hete), water flows down along the surface of the twigs. Some of the water flows down and directly drips down to the ground [27]. 
Equation (15) shows the influence of twigs, $q_{c s}$, and rainfall duration on $T f_{t-d r i p}$. The ratio of water that flows through the branch as $q_{s}$ to $T f_{t-d r i p}$ is influenced by the number of twigs on the branch. In this segment, the concentration of energy that forms the flow in the branches is more influenced by the depth of rainfall than the duration of rainfall. The duration of water trough from the canopy surface had no effect on the increase in flow energy from twigs to branch. Fig. 9 presents the $T f_{t-d r i p}$ of each vegetation.

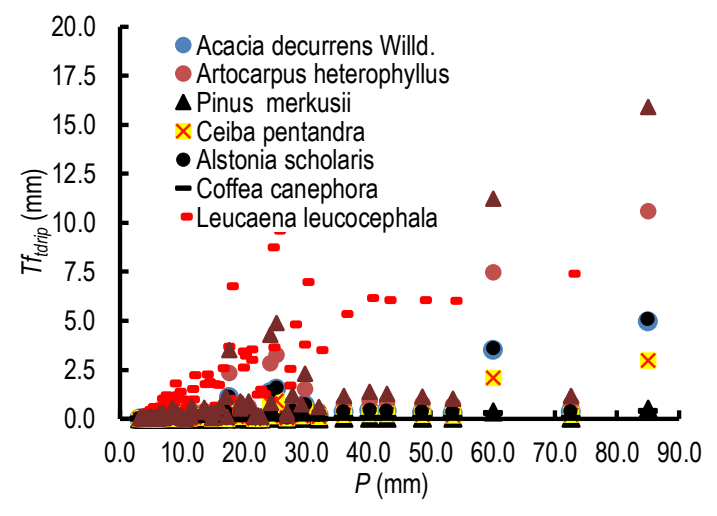

Fig.9 $T f_{t-d r i p}(\mathrm{~mm})$ vs $P(\mathrm{~mm})$

The most profound $T f_{t-d r i p}$ depth was counted on Leucaena leu. and the smallest was on Tectona gran. $T f_{t-d r i p}$ on Tectona gran. increased due to rainfall. $T f_{t-}$ drip on Tectona gran. and $T f_{t-d r i p}$ on Coffea can. has an almost similar value for rainfall less than $50 \mathrm{~mm}$. For rainfall more than $50 \mathrm{~mm}, T f_{t-d r i p}$ on Tectona gran. has a similar $T f_{t-d r i p}$ with Leucaena leu.

This study shows that the density of the canopy structure affects the $T f_{t-d r i p}$ depth. A similar result is found from a previous study stating that the $T f$ depth is affected by the canopy density [28]. ANOVA analysis showed tree species had a significant effect on $T f_{t-d r i p}$ at each test level (Table 4).

Table 4 ANOVA $T f_{t-d r i p}$ test

\begin{tabular}{clcccc}
\hline \multicolumn{2}{c}{$\begin{array}{c}\text { Source of } \\
\text { Variation }\end{array}$} & MS & F & $\begin{array}{c}\text { Fcrit } \\
(5 \%)\end{array}$ & $\begin{array}{c}\text { Fcrit } \\
(1 \%)\end{array}$ \\
\hline \multirow{2}{*}{ Light } & $\mathrm{P}(\mathrm{mm})$ & 1.39 & 1.12 & 5.32 & 11.26 \\
& Species & 14.90 & 12.02 & 3.44 & 6.03 \\
Moderate & $\mathrm{P}(\mathrm{mm})$ & 8.04 & 1.18 & 1.72 & 2.14 \\
& species & 242.24 & 35.55 & 2.01 & 2.65 \\
Heavy & $\mathrm{P}(\mathrm{mm})$ & 35.12 & 1.44 & 1.39 & 1.58 \\
& Species & 1188.56 & 48.85 & 1.96 & 2.56 \\
Very & $\mathrm{P}(\mathrm{mm})$ & 52.58 & 6.11 & 1.83 & 2.33 \\
heavy & Species & 93.42 & 10.85 & 2.11 & 2.84 \\
\hline
\end{tabular}

The calculation result shows that the from light to moderate rainfall intensity has not affected the twigs' throughfall depth. The throughfall from the twigs is affected by heavy rainfall intensity. The depth of rainfall has a significant effect on $5 \%$ of the test level for heavy rainfall intensity. If the analysis range is reduced to $1 \%$, heavy rainfall intensity has no significant effect on the $T f_{t \text {-drip }}$.

The distribution of $T f_{t-d r i p}$ trend against $P$ shows heterogeneous results between the tree species. Similar results are also found for the same species [26]. The distribution of $T f_{t-\text { drip }}$ in more than $25 \mathrm{~mm}$ rainfall depth happens due to the characteristics of the rainfall and trunk characteristics [24] and the roughness of the branches' surface [27].

The twigs that did not drip into $T f_{t-d r i p}$ flows to the branch and become twigs discharge $\left(q_{t}\right)$. The characteristics of branches and twigs significantly affect canopy flow and throughfall. Water that does not drip and flows along the branch is considered to stem discharge $\left(q_{s}\right)$.

The increase in $q s$ during less than 0.35 $\mathrm{mm} /$ minute rainfall intensity did not show a significant difference. Due to increasing rainfall intensity, the difference in $q_{s}$ between tree species becomes more significant. This situation generates a different value between $q_{c s}$ and $q_{t}$. The flow on the branch has either been dripped by gravity or flowed down through the branch. $T f_{t-d r i p}$ and $q_{s}$ calculations show that trees with dominant water droplets from the canopy produced a large recharge concentration to the branches.

The value of $q_{s}$ is calculated using Eq. (19). Based on the calculation, trees that have dominant $T f_{t \text {-drip }}$ produce a large concentration of stem discharge. Fig. 10 shows that an increase in $q_{s}$.

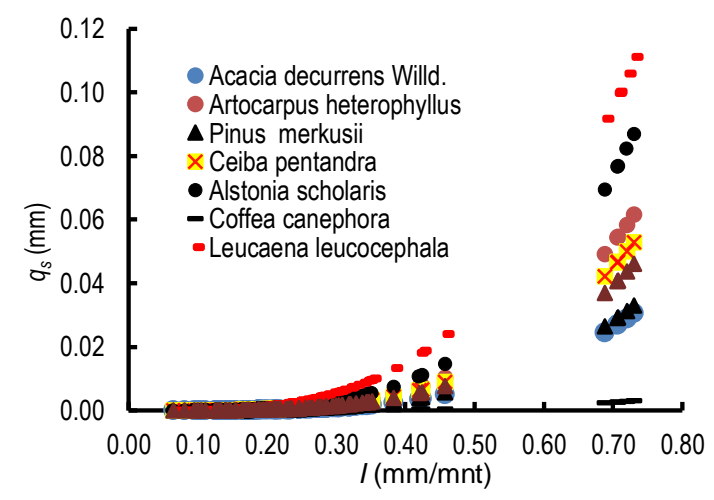

Fig.10 $q_{s}(\mathrm{~mm} / \mathrm{sec})$ vs $I(\mathrm{~mm} / \mathrm{sec})$

The $T f_{\text {s-drip }}$ depth is calculated using Eq. (21). Fig.11. show that the increased rainfall depth has a significant effect on the $T f_{s-d r i p}$ depth. Throughfall at each tree species is affected by canopy characteristics and rainfall depth. Both parameters have a significant influence on the canopy flow concentration [28].

Water flows along the stem is then dripped at a certain point as a can $_{\text {stem-drip }}$ or dripped as $T f_{\text {s-drip. }} . T f_{s-}$ drip and can $_{\text {stem-drip }}$ co-occur or overtake each other. The distribution and characteristics of $T f_{s-d r i p}$ and can $_{\text {stem-drip }}$ are strongly influenced by the canopy 
architecture and characteristics of the branches (Fig.11). ANOVA test is performed to analyze the dominant parameters that influence the $T f_{\text {s-drip }}$ process (Tabel 5). $T f_{s-d r i p}$ is affected by rainfall depth and tree species at the 5\% and $1 \%$ test levels.

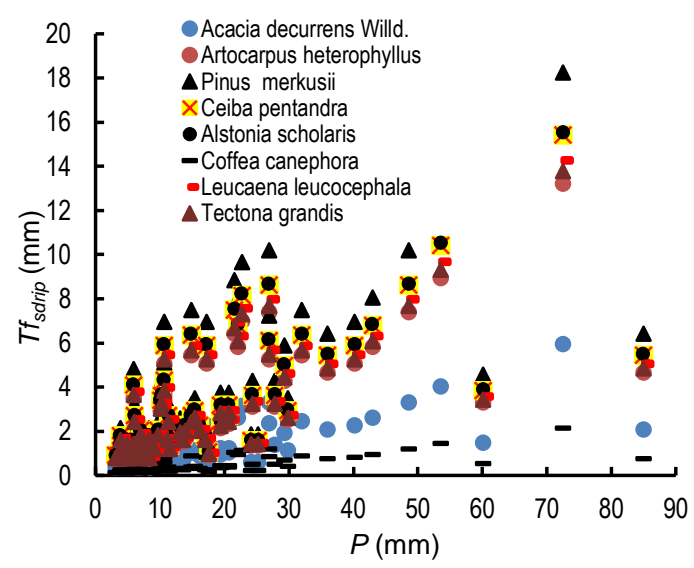

Fig.11 $T f_{s-d r i p}(\mathrm{~mm})$ vs $P(\mathrm{~mm})$

Table 5 ANOVA $T f_{s-d r i p}$ test

\begin{tabular}{cccccc}
\hline \multicolumn{2}{c}{$\begin{array}{c}\text { Source of } \\
\text { Variation }\end{array}$} & MS & F & $\begin{array}{c}\text { Fcrit } \\
(5 \%)\end{array}$ & $\begin{array}{c}\text { Fcrit } \\
(1 \%)\end{array}$ \\
\hline \multirow{2}{*}{ Light } & P $(\mathrm{mm})$ & 14.85 & 18.95 & 5.32 & 11.26 \\
& Species & 9.37 & 11.97 & 3.44 & 6.03 \\
Moderate & $\mathrm{P}(\mathrm{mm})$ & 69.05 & 15.28 & 1.72 & 2.14 \\
& Species & 157.08 & 34.76 & 2.01 & 2.65 \\
Heavy & $\mathrm{P}(\mathrm{mm})$ & 120.10 & 6.27 & 1.39 & 1.58 \\
& Species & 932.96 & 48.67 & 1.96 & 2.56 \\
Very & $\mathrm{P}(\mathrm{mm})$ & 94.17 & 2.03 & 1.82 & 2.31 \\
heavy & Species & 931.59 & 20.05 & 2.03 & 2.69 \\
\hline
\end{tabular}

$T f_{s-d r i p}$ is affected by rainfall depth and tree species at the $5 \%$ and $1 \%$ test levels. The branch structure contributes significantly to the throughfall characteristics [5]. Fragmentation at the droplet concentration and flows from the above segment affects the depth of the $T f_{s-d r i p}$.

Recharge to canopy storage and stemflow inbranch funneling is influenced by the branch structure, branch characteristics, and distribution angle. The depth of can $_{\text {stem-drip }}$ is calculated using Eq. (22). The funneling characteristics of the branches have a significant effect on can $_{\text {stem-drip }}$ presented in Fig. 12.

The recharge process from a twig that flows through the stem becomes the giant droplet on the canopy on Ceiba pent. The minor can $_{\text {stem-drip }}$ calculation is found on Acacia $d$ wild. and Coffea can. In the Leucaena leu., the increase of can $_{\text {stem-drip }}$ is strongly influenced by rainfall intensity. ANOVA determines parameters that have a significant effect on can $_{\text {stem-drip }}$ depth. Rainfall depth did not significantly affect can $_{\text {stem-drip }}$ rate at all rainfall intensity classifications presented at Tabel 6 .
The can $_{\text {stem-drip }}$ is influenced by rainfall intensity at very heavy rainfall. The depth of the can $_{\text {stem-drip }}$ is affected by canopy characteristics for all tree species. Tree species affect the throughfall distribution in all rainfall intensity classifications.

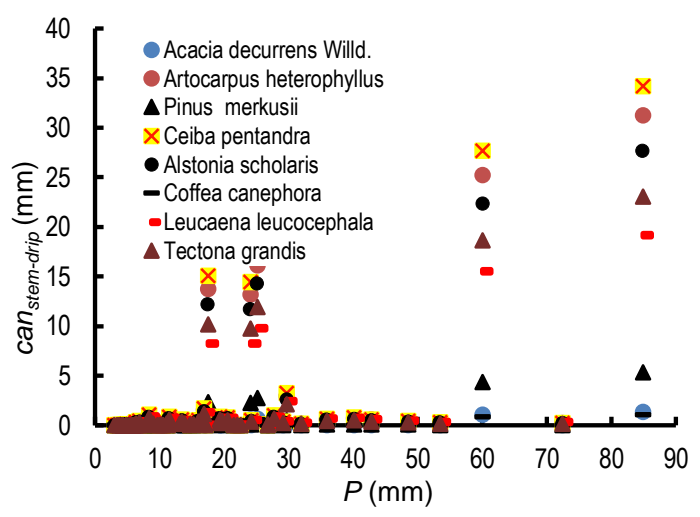

Fig.12 can $_{\text {stem-drip }}(\mathrm{mm})$ vs $P(\mathrm{~mm})$

Table 6 can $_{\text {stem-drip }}$ ANOVA test

\begin{tabular}{cccccc}
\hline \multicolumn{2}{c}{$\begin{array}{c}\text { Source of } \\
\text { Variation }\end{array}$} & MS & F & $\begin{array}{c}\text { Fcrit } \\
(5 \%)\end{array}$ & $\begin{array}{c}\text { Fcrit } \\
(1 \%)\end{array}$ \\
\hline \multirow{2}{*}{ Light } & P (mm) & 1.26 & 1.00 & 5.32 & 11.26 \\
& Species & 15.02 & 11.98 & 3.44 & 6.03 \\
Moderate & P (mm) & 6.97 & 1.01 & 1.72 & 2.14 \\
& Species & 245.67 & 35.52 & 2.01 & 2.65 \\
Heavy & P (mm) & 27.14 & 1.09 & 1.39 & 1.58 \\
& Species & $1,208.84$ & 48.60 & 1.96 & 2.56 \\
Very & P (mm) & 493.81 & 10.29 & 1.82 & 2.31 \\
heavy & Species & 873.24 & 18.19 & 2.03 & 2.69 \\
\hline
\end{tabular}

The stemflow discharge at branches with $\beta_{\mathrm{b}} \geq 60^{\circ}$ and $P>5 \mathrm{~mm}$, gives $80 \%$ of the water flows through the branches. At a branch with an angle of $15^{\circ}$, the flow is $20 \%$. Fig. 13 shows the results of $T f_{\text {empirical }}$. The calculation result is presented in Fig. 13, similar to the previous studies $[4,17]$.

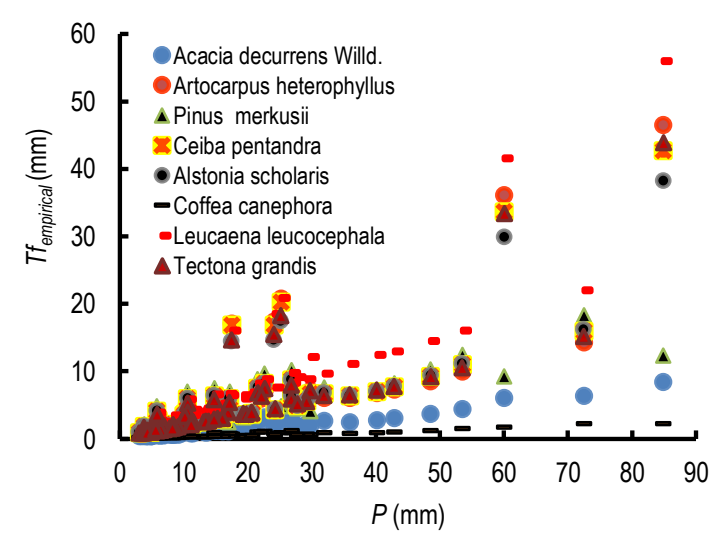

Fig.13. $T f_{\text {empirical }}(\mathrm{mm})$ vs. $P(\mathrm{~mm})$

The parameters that are calculated empirically in this study show the process of rainfall 
distribution to throughfall. ANOVA test shows that the rainfall depth and tree species affect the depth of $T f_{\text {empirical }}$. Tabel 7 shows that the $T f_{\text {empirical }}$ depth of each tree has a significant difference, which depends on the tree characteristics and the rainfall depth.

Table 7. Tf empirical ANOVA test

\begin{tabular}{cccccc}
\hline \multicolumn{2}{c}{$\begin{array}{c}\text { Source of } \\
\text { Variation }\end{array}$} & MS & F & $\begin{array}{c}\text { Fcrit } \\
(5 \%)\end{array}$ & $\begin{array}{c}\text { Fcrit } \\
(1 \%)\end{array}$ \\
\hline \multirow{2}{*}{ Light } & P $(\mathrm{mm})$ & 15.31 & 19.61 & 5.32 & 11.26 \\
& Species & 9.40 & 12.05 & 3.44 & 6.03 \\
Moderate & $\mathrm{P}(\mathrm{mm})$ & 72.48 & 16.16 & 1.72 & 2.14 \\
& Species & 156.11 & 34.80 & 2.01 & 2.65 \\
Heavy & $\mathrm{P}(\mathrm{mm})$ & 144.37 & 7.76 & 1.39 & 1.58 \\
& Species & 902.34 & 48.50 & 1.96 & 2.56 \\
Very & $\mathrm{P}(\mathrm{mm})$ & 963.38 & 18.38 & 1.82 & 2.31 \\
heavy & Species & 829.05 & 15.81 & 2.03 & 2.69 \\
\hline
\end{tabular}

Table 7 and Table 8 have shown that the results of the ANOVA test for observations give similar results with the empirical. Empirical distribution and observations that have been conducted during light rainfall to heavy rainfall show a similar effect on rainfall depth and tree species. The theoretical difference occurs at a very heavy rainfall intensity.

Table 8. $T f_{\text {observed }}$ ANOVA test

\begin{tabular}{cccccc}
\hline \multicolumn{2}{c}{$\begin{array}{c}\text { Source of } \\
\text { Variation }\end{array}$} & MS & F & $\begin{array}{c}\text { Fcrit } \\
(5 \%)\end{array}$ & $\begin{array}{c}\text { Fcrit } \\
(1 \%)\end{array}$ \\
\hline \multirow{2}{*}{ Light } & P $(\mathrm{mm})$ & 19.73 & 15.62 & 5.32 & 11.26 \\
& Species & 11.91 & 9.43 & 3.44 & 6.03 \\
Moderate & $\mathrm{P}(\mathrm{mm})$ & 158.88 & 32.44 & 1.72 & 2.14 \\
& Species & 150.21 & 30.67 & 2.01 & 2.65 \\
Heavy & $\mathrm{P}(\mathrm{mm})$ & 480.37 & 25.77 & 1.39 & 1.58 \\
& Species & 760.93 & 40.82 & 1.96 & 2.56 \\
Very & $\mathrm{P}(\mathrm{mm})$ & 272.46 & 31.80 & 1.83 & 2.33 \\
heavy & Species & 86.94 & 10.15 & 2.11 & 2.84 \\
\hline
\end{tabular}

The relationship between $T f_{\text {empirical }}$ and $T f_{\text {observed }}$ with rainfall intensity $(I)$ can be presented in graphical form (Fig. 14). In this study, the graphical presentation has shown the similar distribution for the $T f_{\text {depth }}$ analysis with $I$ and $P$ (Fig. 14).

This study did not find a very significant difference between $T f_{\text {observed }}$ and $T f_{\text {empirical }}$ in the distribution of total data and calculations. The results of calculations and observations show almost the same distribution. At $I<5 \mathrm{~mm} / \mathrm{hr}$, only $4.5 \%$ caused $T f$ to be evenly distributed under the tree canopies. The depth ratio $T f$ differed slightly at $5<I<10 \mathrm{~mm} / \mathrm{hr}$ for empirical and observed. At $5<\mathrm{I}<10 \mathrm{~mm} / \mathrm{hr}$, Tf $f_{\text {observed }}$ was measured as $20 \%$ of the total rainfall incidence $\left(T f_{\text {empirical }}=19 \%\right)$. The highest $T f$ incidence ratio was obtained at $10<I<20$ $\mathrm{mm} /$ hour. At $10<I<20 \mathrm{~mm} / \mathrm{h}, 58 \%$ Tf was observed simultaneously under the tree canopy $\left(T f_{\text {empirical }}=\right.$
$57 \%$ ). In this study, it was seen that the increased in rainfall intensity up to $>20 \mathrm{~mm} /$ hour did not change the rate of increase in $T f$ depth. At $I>20 \mathrm{~mm} / \mathrm{hour}$, the ratio of $T f$ simultaneously under tree canopy is $17.4 \%\left(T f_{\text {empirical }}=17.1 \%\right)$.

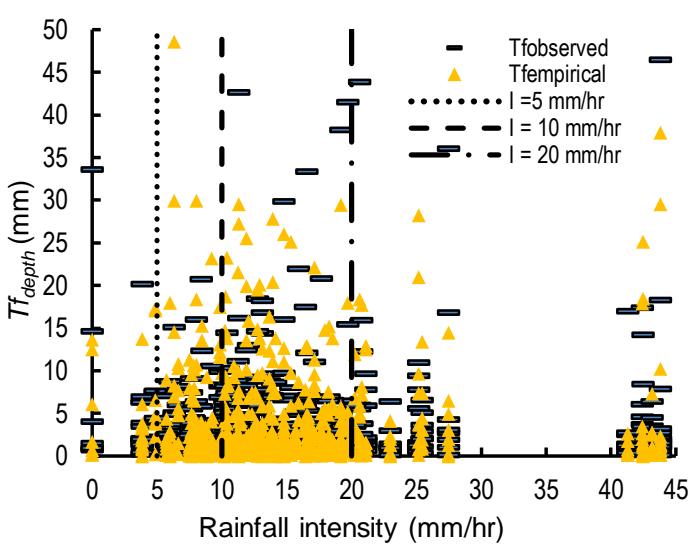

Fig.14. $T f_{\text {depth }}(\mathrm{mm})$ vs. $I(\mathrm{~mm})$

\subsection{Tree Canopy as an Indicator of Post- Eruption Succession}

After the eruption of Merapi Volcano in 2010, most of the vegetation was damaged to several levels. The level of damaged is determined by the distance from the top of the crater, wind direction, and land cover. Landcover damage was also related to the surface flow conditions and hydraulic conditions of the rivers around the Merapi Volcano.

This phenomenon was observed during the rehabilitation phase of the landcover and soil after the eruption of the Merapi Volcano. Landcover succession in dynamic canopy shade (such as Acacia $d$ wild.) was more successful than rigid canopy (such as Arthocarpus hete. and Ceiba pent.).

The Merapi Volcano area is upstream of 3 watersheds, i.e., the Progo in the west, the Opak in the south, and the Begawan Solo in the eastern part. There are 27 rivers flow from these three watersheds. The hydrological impact from the Merapi Volcano eruption also impacts the water availability and tourism activities in this area [32]. The Merapi Volcano eruption in 2010 reduced the springs of Umbul Lanang and Umbul Wadon. These two springs are located in the upper area of Kali Kuning river. Another impact caused by decreasing supply from the spring is the loss of a waterfall in Kaliurang Park.

The interview with residents shows that most of the upstream area at Kali Kuning river became open land after the 2010 eruption. All vegetation in this area was covered by volcanic ash. All leaves were fallen from the trees canopy. The soil substrate in this area is volcanic ash and sand, which is acidic. The species that can grow and develop in the open areas are generally pioneer species. 
Areas with the pioneer vegetation show better recovery capabilities [38]. It can be seen from the land cover under the shade of acacia $d$ wild. On the hilly slopes, there are acacia $\mathrm{d} w$ that grows in the basal area, which is wetter than other areas. In addition, the erosion spot/line in the area is dominated by acacia $d$ wild, which tends to have smaller dimensions than the other areas. The results of this study are similar to previous studies on Mount Merapi [34] for compound leaf vegetation.

\section{CONCLUSION}

This research shows the detailed process of rainfall redistribution in the tropical woody trees canopy. The interactions between the leaves on the canopy surface will affect the dimensions and measured volume of $T f$. The interactions between the leaves and/or twigs show that the canopy is a dynamic structure.

The initial phase of redistribution is the rainfall concentration on each sheet of the canopy surface. The water concentration flows to the next segment of the canopy surface. The flow formed on the canopy surface flows according to the gravity from twigs zone to branches. The process in the segments below the canopy surface is influenced by the branch roughness and the canopy stiffness. As for the dynamic canopy of woody trees, throughfall distribution is spread more evenly below the canopy than the rigid ones.

This condition continues until the entire canopy surface dries up again. Once tree with a rigid canopy has recovered, the stemflow in the rigid canopy species has better condition than the dynamic canopy. The increase in the stemflow ratio and volume has increased the water flow through to the basal area. The basal structure of the tree around Mount Merapi tends to have basal tandon. Increased flow in the basal area will increase the amount of water that can be absorbed and conserved by the soil.

This study did not find a very significant difference between $T f_{\text {observed }}$ and $T f_{\text {empirical }}$ in the distribution of total data and calculations. The results of calculations and observations show almost the same distribution. At $10<I<20 \mathrm{~mm} /$ hour, $58 \% T f_{\text {observed }}$ occurred simultaneously under tree canopies. At this rainfall intensity, the empirical calculation results obtained $57 \%$ of the occurrences simultaneously under the tree canopies. $T f$ did not occur homogeneously under the tree canopy at $I<5$ $\mathrm{mm} /$ hour. The results of $T f_{\text {observed }}$ and $T f_{\text {empirical }}$ showed that at $I<5 \mathrm{~mm} /$ hour, only $4.5 \%$ caused $T f$ to be evenly distributed under the tree canopy.

The results of visual observations during this study showed that the effect of erosion under a rigid canopy was more dominant than that of erosion under a dynamic canopy during the early successional phase. The early phases of post- eruption recovery are the determining factors for post-eruption ecological recovery [39]. More detailed research on the post-eruption succession process in volcanoes is still an interesting research object to be developed in the future.

\section{ACKNOWLEDGMENTS}

This research was conducted with the support of the LPDP (Indonesia Endowment Fund for Education) through the Beasiswa Unggulan Dosen Indonesia (BUDI-DN) program of 2016. The author would like to thank the Petung village community for their support during field data observation. The author would also thank the Department of Civil and Environmental Engineering, Faculty of Engineering, Universitas Gadjah Mada, for supporting this research.

\section{REFERENCES}

[1] Prach K., Tichý L., Lencová K., Adámek M., Koutecký T., Sádlo J., Bartošová A., Novák J., Kovář P., Jírová A., Šmilauer P., Řehounková K. and Bott-Dukát Z., Does succession run towards potential natural vegetation? An analysis across seres, Journal of Vegetation Science, vol. 27, no. 3, pp. 1-13, 2016.

[2] Chang C. C., Halpern C. B., Antos J. A., Avolio M. L., Biswas A., Cook J. E., del Moral R., Fischer D. G., Holz A., Pabst R. J., Swanson M. E. and Zobel D. B., Testing conceptual models of early plant succession across a disturbance gradient, Journal of Ecology (Oxford), vol. 107, no. 2, pp. 517-530, 2019.

[3] The Yogyakarta Geological Disaster Technology Research and Development Center, Annual Report 2020, Kementerian Energi dan Sumber Daya Mineral, Yogyakarta - Indonesia, 2020.

[4] Nanko K., Onda Y., Ito A., and Moriwaki H., Effect of canopy thickness and canopy saturation on the amount and kinetic energy of troughfall: An experimental approach, Geophysical Research Letters, p. L05401, 2008.

[5] Wang A., Diao Y., Pei T., Jin C., and Zhu J., A semi-theoritical model of canopy rainfall interception for a broad-leaved tree, Hydrologycal Processes, vol. 21, pp. 2458-2463, May 2007.

[6] Azmeri and Isa A. H., An Analysis of Physical Vulnerability to Flash Floods in the small Mountainous Watershed of Aceh Besar Regency, Aceh Province, Indonesia, Jàmbá Journal of Disaster Risk Studies, vol. 10, no. 1, pp. 1-6, 2018.

[7] Livesley S., Baudinette B., and Glover D., Rainfall interception and stem flow by eucalypt street trees - The impacts of canopy density and 
bark type, Urban Forestry \& Urban Greening, vol. 13, pp. 192-197, 2014.

[8] Levia D. F., Hudson S. A., Llorens P., and Nanko K., Throughfall drop size distributions: A review and prospectus for future research, WIREs Water, vol. 4, pp. 1-18, 2017.

[9] Wang W.-M., Li Z.-L., and $\mathrm{Su}$ H.-B., Comparison of leaf angle distribution functions; Effects on extinction coefficient and fraction of sunlit foliage, Agricultural and Forest Meteorology, vol. 143, pp. 106-122, 2007.

[10] Aparecido L. M., Miller G. R., Cahill A. T., and Moore G. W., Leaf surface traits and water storage retention affect photosynthetic responses to leaf surface wetness among wet tropical forest and semiarid savanna plants, Tree Physiology, vol. 37, pp. 1285-1300, 2017.

[11] Staelens J., Schrijve A. D., Verheyen K., and Verhoes N., Rainfall partitioning into throughfall, stemflow, and interception within a single beech (Fagus sylvatica L.) canopy: influence of foliation, rain event characteristics, and meteorology, Hydrological Processes, vol. 22, pp. $33-45,2008$.

[12] Haverd V., Lovell J., Cuntzc M., Juppa D., Newnham G., and Sea W., The Canopy Semianalytic Pgap And Radiative Transfer (CanSPART) model: Formulation and application, Agricultural and Forest Meteorology, vol. 160, pp. 14-35, 2012.

[13] Goel N. S., and Strebel D. E., Simple Beta Distribution Representation of Leaf Orientation in Vegetation Canopies, Agronomy Journal, vol. 76, no. 5, pp. 800-802, 1984.

[14] Herwitz S. R., Raindrop impact and water flow on the vegetative surfaces of trees and the effects on stemflow and throughfall generation, Earth Surface Processes and Landform, vol. 12, pp. 425-423, 1987.

[15] Gash J. H. C., Lloyd C. R., and Lachaud G., Estimating sparce forest rainfall interception with an analytical model, Journal of Hydrology, vol. 170, pp. 79-86, 1995.

[16] Verhoef W., Light Scattering by Leaf Layers with Application to Canopy Reflectance Modeling: The SAIL Model, Remote Sensing and Environment, vol. 16, no. 2, pp. 125-141, 1984.

[17] Keim R., Skaugset A., and Weiler M., Storage of water on vegetation under simulated rainfall of varying intensity, Advances in Water Resources, vol. 29, pp. 974-986, 2006.

[18] Xiao Q., McPherson E. G., Ustin S. L., and Grismer M. E., A new approach to modelling tree rainfall interception, Journal of Geophysical Research, vol. 105, pp. 29.173-29.188, December 2000.

[19] Frazer G., Canham C., and Lertzman K. 1., Gap Light Analyzer (GLA), Version 2.0: Imaging software to extract canopy structure and gap light transmission indices from true-colour fisheye photographs, users manual and program documentation, Simon Fraser University, Burnaby, British Columbia, and the Institute of Ecosystem Studies, Millbrook, New York., 1999.

[20]Li X., Xiao Q., Niu J., Dymond S., van Doorn N. S., and $\mathrm{Yu} X$., Process-based rainfall interception by small trees in Northern China: The effect of rainfall traits and crown structure characteristics, Agriculture and Forest Meteorology, pp. 65-73, 2016.

[21] Loescher H. W., Powers J. S. and Oberbauer S. F., Spatial Variation of Throughfall Volume in an Old-Growth Tropical Wet Forest, Costa Rica, Journal of Tropical Ecology, vol. 18, no. 3, pp. 397-407, 2002.

[22] Hashino M., Yao H., and Yoshida H., Studies And Evaluations On Interception Processes During Rainfall Based On A Tank Model, Journal of Hydrology, pp. 1-11, 2002.

[23] Ahmad R. K., Sujono J., and Jayadi R., Canopy saturation and troughfall for accaciella angustissima, arturocarpus heterohyllus, pinus merkusii and athocephalus cadamba related to rainfall intensity, in 21th IAHR-APD Congress, Yogyakarta, 2018.

[24] Holder C. D., and Gibbes C., Influence of leaf and canopy characteristics on rainfall interception and hydrology, Hydrological Sciences Journal, pp. 1-9, 2016.

[25] He Z.-B., Yang J.-J., Du J., Zhao W.-Z., Liu H., and Chang X.-X., Spatial variability of canopy interception in a spruce forest of the semiarid mountain regions of China, Agricultural and Forest Meteorology, vol. 188, p. 58-63, 2014.

[26] Crockford R., and Richardson D. P., Partitioning of rainfall in a eucalypt forest and pine plantation in southeastern Australia: IV the relationship of interception and canopy storage capacity, the interception of these forests, and the effect on interception of thinning the pine plantation, Hydrological Processes, vol. 4, no. 2, pp. 168-188, 1990.

[27] Klamerus-Iwan A., Rainfall parameters affect canopy storage capacity under controlled conditions, Forest Research Papers, vol. 75, no. 4, pp. 353-358, 2014.

[28]Levia D. F., Nanko K., Amasaki H., Giambelluca T. W., Hotta N., Iida S., Mudd R. G., Nullet M. A., Sakai N., Shinohara Y., Sun X., Suzuki M., Tanaka N., Tantasirin C., and Yam, Throughfall partitioning by trees, Hydrological Processes, vol. 33, p. 1698-1708, 2019.

[29] Crockford R. H., and Richardson D. P., Partitioning of raifall into troughfall stemflow and interception: effect of forest type, ground 
cover and climate, Hydrology Processes, vol. 14, no. 16-17, pp. 2903-2920, 2000.

[30] Sujono J., Jayadi R., Nurrochmad F., Heavy Rainfall Characteristics At South-West Of Mt. Merapi - Yogyakarta And Central Java Province, Indonesia, International Journal of GEOMATE, vol. 14, no. 45, pp. 184-191, 2018.

[31] Calder I. R., A stochastic model of rainfall interception, Journal of Hydrology, vol. 89, pp. 65-71, 1986.

[32] Gunawan H., Sugiarti, Wardani M., Tata M. H. L., and Prajadinata, Restoration of the PostEruption Merapi Volcano Ecosystem (Restorasi Ekosistem Gunung Merapi Pasca Erupsi), Research and Development Center for Conservation and Rehabilitation - Forestry Research and Development Agency, Ministry of Forestry (Pusat Penelitian dan Pengembangan Konservasi dan Rehabilitasi - Badan Penelitian dan Pengembangan Kehutanan Kementerian Kehutanan), Bogor, 2013.

[33] Alviawati E., Livelihood strategies for dairy farmers in Kepuharjo Village, Cangkringan District, before and after the 2010 Merapi eruption (Strategi penghidupan rumahtangga peternak sapi perah di Desa Kepuharjo Kecamatan Cangkringan pra dan pasca erupsi Merapi 2010), Majalah Geografi Indonesia, vol. 27, no. 2, pp. 104-117, 2013.

[34] Gunawan H., Heriyanto N. M., Subiandono E., Mas'ud A. F., and Krisnawati H., Invasion of exotic species in post-eruption degraded areas in Merapi Volcano National Park (Invasi jenis eksotis pada areal terdegradasi pasca erupsi di Taman Nasional Gunung Merapi), in Seminar Nasional Masyarakat Biodiv. Indonesia, Yogyakarta, 2015.

[35] Horton R. E., Rainfall Interception, Mountly Weather Review 47, pp. 608-623, 1919.

[36] Gash J. H. C., An Analytical Model of Rainfall Interception by Forests, Journal of Royal Meteorology, vol. 105, pp. 43-45, 1979.

[37] Badan Meteorologi Klimatologi dan Geofisika Indonesia, Standar Penentuan Iklim /Meteorological, Climatological, and Geophysical Agency of Indonesia, Climate Determination Standard, 1990.

[38] Dohnal M., Černý T., Votrubová J., and Tesař M., Rainfall interception and spatial variability of throughfall in spruce stand, J. Hydrol. Hydromech., vol. 62, no. 4, p. 277-284, 2014.

[39] Putra T. H. A., Istijono B., Aprisal, Rusman B., Ophiyandri T., Putra, T. H. A.; Istijono, B.; Aprisal; B., Rusman; T., Ophiyandri, The Dynamics Of Land Cover Change And Causal Factors In The Kuranji Watershed, International Journal of GEOMATE, pp. 69-75, 2021.

Copyright $\odot$ Int. J. of GEOMATE All rights reserved, including making copies unless permission is obtained from the copyright proprietors. 